\title{
Congruency of tumour volume delineated by FET PET and MRSI
}

\author{
Jörg Mauler ${ }^{1 *}$, Karl-Josef Langen ${ }^{1}$, Andrew A Maudsley ${ }^{2}$, Omid Nikoubashman $^{3}$, Christian Filss ${ }^{1}$, Gabriele Stoffels ${ }^{1}$, \\ $\mathrm{N}$ Jon Shah ${ }^{1}$ \\ From PSMR 2015: 4th Conference on PET/MR and SPECT/MR \\ La Biodola, Isola d'Elba, Italy. 17-21 May 2015
}

'Institute of Neuroscience and Medicine, Forschungszentrum Jülich, Germany
In addition to MR imaging, PET imaging of O-(2-[18F]Fluorethyl)-L-Tyrosine (FET) uptake provides information on brain tumour extent and metabolic activity. Similarly, MRS has been shown to be of value for distinguishing high- from low-grade gliomas. Based on 2D spatially resolved MRSI, an overlap between 18FET uptake and the choline/N-acetyl-aspartate (Cho/NAA) ratio of more than $75 \%$ has been reported.

\section{Aim}

To measure spatial correlation of 18FET-PET with 3D spatially resolved MRSI in patients with gliomas.

\section{Methods}

14 patients $(46 \pm 16$ y) with gliomas (WHO grade II-IV) were examined by simultaneous 18FET-PET-3D-MRSI measurements which covered the whole brain (Siemens BrainPET/3T MR TIM Trio; MRSI: EPSI sequence, TE=17.6 ms). The data were analysed with respect to the congruency of the suspicious tissue delineated by the FET uptake and the Cho/NAA ratio. Locations of individual maxima and distances in between were determined. The congruency of the tumour was assessed using Dice's coefficients for assumed same tumour volume. All comparisons were carried out at the spatial resolution of the whole brain spectroscopic image $\left(64 \times 64 \times 32 \mathrm{v} \times 1,5.6 \times 5.6 \times 10 \mathrm{~mm}^{3}\right.$ each).

\section{Results}

The intensity maxima of both modalities were $(61 \pm 51) \mathrm{mm}$ distant from each other. The average level of congruency between the tumour volumes delineated in the FET uptake and MRSI data was $(33 \pm 25) \%$. Metabolically active tumour tissue, as depicted by FET uptake, is represented to a low extent by the choline/N-acetyl-aspartate ratio measured by spatially resolved 3D MRSI, which is in contrast to previous findings. Both modalities may reflect independent physiological properties of gliomas.

\section{Authors' details}

${ }^{1}$ Institute of Neuroscience and Medicine, Forschungszentrum Jülich, Germany. ${ }^{2}$ Miller School of Medicine, University of Miami, USA. ${ }^{3}$ Department of Neuroradiology, Faculty of Medicine, RWTH Aachen University, Germany.

\section{SpringerOpen ${ }^{\infty}$}

(C) 2015 Muller et al; licensee Springer. This is an Open Access article distributed under the terms of the Creative Commons Attribution License (http://creativecommons.org/licenses/by/4.0), which permits unrestricted use, distribution, and reproduction in any medium, provided the original work is properly cited. 

2015 2(Suppl 1):A61.

Submit your manuscript to a SpringerOpen ${ }^{\odot}$ journal and benefit from:

- Convenient online submission

- Rigorous peer review

- Immediate publication on acceptance

- Open access: articles freely available online

- High visibility within the field

- Retaining the copyright to your article

Submit your next manuscript at $\gg$ springeropen.com 